\title{
'The Age of Veneer': Charles Dickens and the antinomies of Victorian consumer culture
}

Peter Gurney, Department of History, University of Essex, UK.

The bicentenary of the birth of Charles Dickens in 2012 was celebrated in myriad ways across the English-speaking world and beyond. Building on the long-standing tradition of heritage appropriations of his work, the "Dickens industry" made full use of the commercial opportunities: in Britain, a major new biography was serialised on Radio 4, while reworkings of Dickens's novels were an almost omnipresent feature on television (see John 240-89). A dominant motif of this outpouring was Dickens's "humanitarianism," especially his sympathy for the poor and his injunctions to the rich on the duty of Christian charity. Surprisingly, given the ongoing economic crisis, Dickens's attitude towards material greed went largely unremarked despite the fact that Our Mutual Friend, his last completed novel published in 1865 , unreservedly damned the rich for their conspicuous consumption practices. His critique of the Veneerings and their circle and, by extension, the trajectory of British society in the "age of capital," is all the more remarkable when we remember that Dickens was far from being a radical himself; he had embraced free trade in the mid 1840s and although he had conflicting feelings about capitalist modernity, Dickens had little time for attempts by either working-class Chartists or paternalistic Tories to regulate industrial "progress" (Slater).

Precisely such contradictions make Dickens so interesting. Although he experienced the commodity culture on display at the Great Exhibition as a kind of drowning, Dickens also revelled in the excesses of Victorian consumerism. ${ }^{1}$ Dressed "in high satin stock and double 
breast pin, in glossy frock coat and velvet collar, in cut velvet waistcoat and glittering chain," as a young man he presented himself as a dandy on the streets of London. On his first visit to America in 1842 one newspaper complained that Dickens's "whole appearance is foppish...and partakes of the flash order" (Ackroyd 349). Like many bourgeois paterfamilias, he did not have to be cajoled into accompanying his wife Catherine on shopping trips and derived real pleasure from beautifying domestic space. Dickens redecorated Tavistock House in lavish fashion after moving there towards the end of 1851, provoking George Eliot's caustic question: "How can we sufficiently pity the needy unless we know fully the blessings of plenty?” (Ackroyd 648). George Orwell once noted in a perceptive essay how Dickens's work was vitally concerned with understanding "a city of consumers," and that he observed the social world primarily "from the consumer-angle...the kind of things he notices are innsigns, brass door-knockers, painted jugs, the interiors of shops and private houses, clothes, faces and, above all, food" $(115,118)$. Moreover, Dickens's writing was itself imbricated within a growing consumer culture. Many firms, including producers of branded goods such as Colman's mustard and Pears' soap, advertised in the inserts bound in with the serial parts of his novels. After he died tea dealers and others promoted their goods by giving away free copies of his works. ${ }^{2}$ Dickens understood the new consumerism from the inside.

According to Dickens's late work, modern consumerism depended on harnessing acquisitiveness more effectively than ever before. Again, he had no doubts about the benefits that had resulted from the spread of material things made possible by free trade capitalism; his own dislocated childhood experiences made it easier for him to see though puritan yearnings for the simple life. However, in his last decade especially, Dickens foregrounded the moral bankruptcy of a culture that revolved around the acquisition of goods. The financial scandals that rocked Victorian society in the 1860s shaped his increasingly bleak vision and 
scholarship has shed much light on this historical context. Fears of impending financial crisis were rife when Our Mutual Friend was being serialized and in 1866 Overend, Gurney \& Co., a major wholesale discount bank, collapsed and brought down over 200 companies with it. Vicious attacks on the principle of limited liability and stock market speculation were commonly made by middle-class journalists and novelists. ${ }^{3}$ However, it would be misleading to make too much of this; the weak response of the parliamentary select committee set up after the crisis underlined the fact that there was to be no going back to the situation before limited liability legislation was passed in the mid 1850s. Indeed, as Mary Poovey has pointed out, criticism itself served to normalize the operations of financial institutions and assure middle-class investors about the morality of business ("Writing about finance"). Dickens's critique was of a quite different order: although his denunciation of speculation and financial wrongdoing plays a vital role in this novel as it did in so many other works of canonical and non-canonical Victorian fiction, it is part of a much wider attack on an emergent consumer culture. In short, such immoral practices are not merely unfortunate aspects of an otherwise beneficial system that can easily be reformed but are rather symptoms of a much wider pathology - a diseased consumer culture that situates the insatiable consumption of material goods at the centre of personal as well as social and economic life.

The article is divided into two parts. The first begins with a consideration of Dickens's treatment of the theme of reification in a novel in which things are continually turning into people and vice versa. For Dickens, as for Marx, this is an inevitable result of a society where market values have been elevated above everything else. Unlike Marx, however, Dickens had much to say about the quotidian realities of a reified consumer culture characterised by adulteration and the desire for novelty (Finn 6-7). The depthless, "sticky" Veneerings, who are mired in an immoral world of false dealing and glittering excess, 
concentrates these key themes. The article then moves on to discuss Dickens's unsatisfactory resolution of the contradictions exposed in the work. Two solutions are proposed: a more authentically human appropriation of commodities prefigured by a child's world of "toy wonders," and the equally problematic cult of the home or the "domestic virtues."

\section{Pathologizing Victorian consumer culture}

Dickens's sense of the commodification of daily life became more acute after mid-century. As James Brown argued some years ago, at the core of Dickens's mature works, "is the obsessively recurring metaphor of society as one huge market-place" (23; see also Hoppen 390-1). Our Mutual Friend represented a culture in which the market for consumer goods assumed determining force. The plot consists of a tangle of improbabilities, focussing on an inheritance of valuable dust heaps that pass to Nicodemus Boffin, "The Golden Dustman," when John Harmon, the son of a rich miser and Boffin's old employer, is found drowned in the Thames. The major theme is announced in chapter one when Gaffer Hexam and his daughter, who make a living scavenging the river for corpses, drag out what is thought to be Harmon's body. Gaffer takes money from the dead man's pocket: "He chinked it once, and he blew upon it once, and he spat upon it once, - 'for luck,' he hoarsely said - before he put it in his pocket" (14; bk. 1, ch.1). That chink strikes the keynote: everything in the novel revolves around the commodity of commodities, without which life is impossible but which also necessarily deforms human relationships. Taken up by Boffin and his wife later in the novel, the mercenary Bella Wilfer exclaims, "“think how terrible the fascination of money is! I see this, and hate this, and dread this, and don't know but that money might make a much worse change in me. And yet I have money always in my thoughts and my desires; and the whole life I place before myself is money, money, money, and what money can make of life!"” (455; bk. 3, ch. 4). Like Marx, Dickens knew that commodities were mysterious things 
and the universal commodity was most mysterious of all. The two major symbols in the novel, the river Thames and Boffin's dust heaps, are subject to continual circulation and transmogrification; they flow and accumulate like money and, like money, can bring about life or death. Our Mutual Friend is centrally concerned with the effects of "mammon," the inordinate pursuit of wealth, which Dickens considered was now the guiding principle of Victorian society.

Though Dickens was closer to Douglas Jerrold than to Thomas Carlyle on many things, here the influence of the latter was profound and continuing (Stedman Jones). The elevation of money above all else, until for some it had even assumed the role of religion "Mammonism" was Thomas Carlyle's preferred neologism - had at last produced a thoroughly reified social life. ${ }^{4}$ This theme was already present in Dombey and Son (1848) but in that work there was at least some hope of salvation for the individual capitalist. Our Mutual Friend generalized the critique and offered readers only a number of dead ends. For sure, Dickens understood the power of money in relation to his own work as a writer for an emerging mass market very well and his canny wrangling over copyrights and royalties have been exhaustively documented. ${ }^{5}$ To what extent these particular conflicts coloured his outlook is open to question but this much is clear; reification is built into the fundamental structure of his last novel. Literary scholars noted this aspect of Dickens's work years ago, though it has still not received the attention it deserves perhaps. ${ }^{6}$ The Veneerings, for instance, "bran-new people" who have made their money from stock market speculation and quack medicines, are mere surface impressions who systematically conflate people with things: "Everything about the Veneerings was spick and span new. All their furniture was new, all their friends were new, all their servants were new, their plate was new... what was observable in the furniture, was observable in the Veneerings - the surface smelt a little too 
much of the workshop and was a trifle sticky" (17; bk. 1, c. 2). The Veneerings' dinner parties are a central feature in the novel, at which the unassuming Twemlow - "an innocent piece of dinner-furniture that went upon easy castors" - is an omnipresent figure, valued only for his distant aristocratic connections. Lady Tippins provides an insider's view of this world when she "checks off” the Lammles' wedding party: “"Bride; five-and-forty if a day, thirty shillings a yard, veil fifteen pound, pocket-handkerchief a present. Bridesmaids; kept down for fear of outshining bride, consequently not girls, twelve and sixpence a yard...Mrs. Veneering; never saw such velvet, say two thousand pounds as she stands, absolute jeweler's window"' (123; bk. 1, ch. 10). Lady Tippins reads people as commodities who might just as well have their exchange values tattooed on their foreheads. Bourgeois society Dickens implies is thoroughly cynical and cold, punctuated by a never-ending round of hollow rituals, a view which not surprisingly was fiercely contested when the novel first appeared (Saturday Review: 612).

The superficiality and essentially fraudulent nature of the Veneerings and their circle is reiterated in the text. Like mass-produced capitalist commodities, people such as the Veneerings are all show and image, as their name underlines. It would be as foolish to trust such people as it would to put ones faith in shoddy goods. They are linked to the immoral and often dangerous practices of adulteration by their ownership of a drug house, "Chicksey, Veneering, and Stobbles," situated in Mincing Lane, an area that specialized in the production of drugs, perfumes and dyes and a renowned centre of adulterative practice. To emphasise the point, Dickens refers to one of the Veneerings' servants as the Analytical Chemist, “always seeming to say, after 'Chablis, sir?' - 'You wouldn't if you knew what it's made of"” (20; bk. 1, ch. 2). An archetypal gullible consumer, Twemlow "feels a little queer on the sofa" towards the end of the novel, "in consequence of having taken two advertised 
pills at about mid-day, on the faith of the printed representation accompanying the box" (605; bk. 3, ch. 17). Here Dickens was mocking those foolish enough to be persuaded by the fraudulent claims made for patent or "quack" medicines such as Holloway's Pills, which were among the first consumer goods to be branded and advertised nationally (Fraser, Church). Supported by Thomas Wakley, Dr Arthur Hassell's revelations in the Lancet in the early 1850 s and the public campaign that followed led to legislative intervention against the worst forms of food adulteration in 1860 , though this proved woefully ineffective. ${ }^{7}$ In Dickens's novel, adulteration is configured as a typical characteristic of modern life, not simply an anomaly of the market place but a persistent, structural feature. Dickens was not alone here: a series of articles in Fraser's Magazine entitled “The Age of Veneer" had developed this idea more than a decade earlier. The writer of these claimed that what had originally been a method of making cheap furniture look expensive had assumed a more general significance, a "universal moral veneering," which affected education and politics as well as material goods. The average Englishman, the writer asserted, "is becoming superficial and unreal in everything. In mind and body he is veneered." Adulteration and modern advertising were distinctive symptoms of the age; future generations would regard political reform as "trifles," whereas "steam locomotion and the puff-advertisement system" would together constitute "the grandest of world phenomena" ("The Age of Veneer").

Inanimate things are forever turning into sentient creatures in Our Mutual Friend. Even shares, the most abstract of commodities on which the Veneerings and company depend, are personified and represented by Dickens as unfeeling deities who dominate puny, drugged mortals: "O mighty Shares! To set those blaring images so high, and to cause us smaller vermin, as under the influence of henbane or opium, to cry out, night and day, 'Relieve us of our money, scatter it for us, buy us and sell us, ruin us, only we beseech ye 
take rank among the powers of the earth, and fatten on us!"' (118; bk. 1, ch. 10). However, the most memorable example of this textual strategy in the novel concerns the Veneerings' table decorations, gold and silver camels deployed to dazzle and impress their guests. We first see them mirrored in the great dining room looking glass that; "Reflects the new Veneering crest, in gold and eke in silver, frosted and also thawed, a camel of all work. The Herald's College found out a Crusading ancestor for Veneering who bore a camel on his shield (or might have done if he had thought of it), and a caravan of camels take charge of the fruits and flowers and candles, and kneel down to be loaded with the salt" (21; bk. 1, ch. 2). This is quintessentially a world of mirrors and appearances, of bright, glittering reflections that obfuscate the reality of underlying social relationships. The Veneerings have taken up the image of the camel in a pathetic attempt to identify their name with a romantic, heroic past but the result of course is merely ludicrous. They are tied to these camels throughout the novel until the reader wonders which the beast of burden is. They seem to have a life of their own, "take charge of the fruits and flowers and candles, and kneel down to be loaded with the salt." When Lady Tippins works to get Mr Veneering elected Member of Parliament for Pocket-Breaches, she recommends him thus: "“You really ought to see their gold and silver camels, I call their dinner-table, the Caravan"” (249; bk. 2, ch. 3). When the Veneerings hold a dinner party to mark the Lammles' financial ruin, we are told that the "camels are polishing up in the Analytical's pantry" (605; bk. 3, ch. 17).

Elaine Freedgood has argued that canonical Victorian novels might be better illuminated by close analysis of their "thing culture," and restores goods such as mahogany furniture, calico and Negro head tobacco to their appropriate historical contexts (7-8). The Veneerings' camels lend themselves to such an approach, pregnant as they are with metonymic meaning. They were most likely produced by a firm such as Elkington, Mason 
and Company of Birmingham, which specialized in the new processes of electro-gilding and plating that brought art-manufactures within reach of more and more middle-class consumers from around mid-century ("The Magic Troughs at Birmingham"; Briggs, 25, 73). Camels signified an exotic Orientalism that exerted a powerful fascination; Richard Burton's travel writings about the Middle East helped to popularize a fashionable interest in nomadic, supposedly uncivilized cultures ("The British Dervish"; see also Buzard, and Said 194-7). For the Veneerings, then, their "camel of all work" simultaneously gestured towards a bloody but progressive history and provided a form of conspicuous consumption. The Veneerings were, however, less likely to intuit other significances that suggest themselves: the nomadic character of finance capitalism, on which the Veneerings depended, for instance; or even Matthew 19/24 - "It is easier for a camel to go through the eye of a needle, than for a rich man to enter into the kingdom of God." Camels could spit at and even sometimes bite their owners.

Social groups towards the top of the social pyramid, such as the Veneerings, as well as archetypal representatives of proletarian culture, are brutalized and demoralized by the corrupting power of money (Maidment 205). Dickens explores the latter group through the characters of "The Golden Dustman" and his wife, the effects of newly acquired wealth traced in their changing attitudes towards material culture. Boffin develops into a miser, (or at least pretends to do so), while his wife becomes in his words, "a highflyer at Fashion." Early in the novel we see Mrs Boffin wearing a "low evening-dress of sable satin, and a large black velvet hat and feathers," while her husband, who still prefers "comfort," sports an "undress garment of short white smock-frock." The interior of their cosy living space is a heterogeneous mix of old and new styles, spontaneously juxtaposed. Partly done out like "a luxurious amateur tap-room," a new influence can also be discerned: "Facing the fire between 
the settles, a sofa, a footstool, and a little table, formed a centrepiece devoted to Mrs Boffin. They were garish in taste and color, but were expensive articles of drawing-room furniture that had a very odd look beside the settles and the flaring gaslight pendent from the ceiling" (63; bk. 1, ch. 5). Initially, Boffin hopes to strike a balance between "Comfort" and "Fashion" but his wife's view eventually carries the day and they move to an "Eminently Aristocratic Mansion" and surround themselves with fashionable things. However, their seduction by the new consumerism does not stop them trying to use their wealth to improve the lives of others; they adopt Bella Wilfer who had been betrothed to Harmon's son and was therefore set to gain. And even in the grand new house Boffin fits out a room of his own with "no pretensions to velvet, satin or gilding," which the family retires to when they want to enjoy "a particularly pleasant fireside evening" (456; bk. 3, ch. 5). Eventually the money-mad Bella is heartbroken by Boffin's apparent transformation into a miser; he obsessively collects "Lives of Misers" and declaims that they "must scrunch or be scrunched"” (470; bk. 3, ch. 6). Bella flees from the house when Boffin accuses his secretary Rokesmith, who is in reality John Harmon, of being no more than a gold-digger and it becomes clear that she too will be inevitably commodified: “"This young lady was looking about the market for a good bid; she wasn't in it to be snapped up by fellows that had no money to lay out; nothing to buy with"' (578; bk. 3, ch. 15). Significantly, when she quits Bella throws off the fashionable dress the Boffins' had provided, an action thoroughly approved by her father: “"And therefore...this mercenary young person distantly related to myself, refused the price, took off the splendid fashions that were part of it, put on the comparatively poor dress that I had last given her, and trusting to my supporting her in what was right, came straight to me"” (594; bk. 3, ch. 16).

The discourse on fashion in Our Mutual Friend reflects Dickens's stance in the contemporary debate on "taste" and the decorative arts. From the late 1840s, an emergent 
group of taste professionals and designers had castigated middle-class consumers for their ignorance and lack of discernment. Reformers such as Henry Cole, Owen Jones and Ralph Wornum, disparaged the undisciplined mixing of styles and the emphasis on elaborate ornamentation rather than principles of good design, which they believed characterized bourgeois taste. ${ }^{8}$ Their efforts received a considerable fillip from the Great Exhibition in 1851; Cole helped organize it and Jones designed the controversial polychromatic colour scheme, while Wornum published a prize essay on the exhibition as a lesson in taste. After the event, Cole and his supporters established a Museum of Ornamental Art at Marlborough House, the most popular attraction of which was a Chamber of Horrors, where blatant examples of bad taste were exhibited (see Pevsner 152, Cohen 20-24). Jones gave a series of lectures here in the summer of 1852 in which he attacked architecture and the decorative arts for lacking a coherent philosophy appropriate to the age. He believed that the Victorian period was obsessed by wealth and that consumers needed to be schooled in sound design principles - "the cultivation of the eye" was Jones's felicitous phrase - so that they could demand the right kind of goods (41). More generally, he argued that capitalist culture required its own distinctive visual language and he later outlined the basic structure of this new code in his celebrated work, The Grammar of Ornament (1856), which detailed thirtyseven key propositions. Some of Dickens's peers swallowed this completely, including George Eliot who reviewed the work enthusiastically and employed Jones to design the interior of the house she moved into with G. H. Lewes in 1863 ("The Grammar of Ornament," Miller). Dickens, as the discussion above indicates, was far more sceptical about taste reform, regarding it as yet another attempt at system building and like Boffin advocated flexibility and toleration instead. He approved of Henry Morley's satirization of the Chamber of Horrors that was published in Household Words and even ridiculed Cole himself in Hard Times ("A House Full of Horrors;" see also Fielding). Dickens revelled in the messiness of 
social life that taste reformers wanted to tidy up. However, the differences between them derived from other sources as well. Jones, for example, believed that a specifically capitalist art was necessary to express the age of mammon now that religion no longer provided a unifying centre (Jones 42-4). Dickens wanted to moralize the world of goods, not by means of abstract rules but by the regeneration of a humanistic Christianity across all classes (Walder).

\section{Beyond reification: "toy wonders" and "domestic virtues"}

Society may be thoroughly reified in Dickens's later work but his representation of the commodity should not be confused with Marx's notion of commodity fetishism outlined in the first volume of Capital, published two years after Our Mutual Friend appeared. Certainly, Dickens shared with Marx an appreciation of the "mysterious" or "phantasmagorical" nature of the commodity form and frequently emphasized its fetishistic nature as we have seen. He was also fully aware of the way in which labour was frequently occluded in Victorian society and encouraged the publication of many "process articles," which uncovered the history embedded in particular commodities, in Household Words during the 1850s. One of these by Charles Knight, editor of the Penny Magazine, for example, celebrated the Christmas pudding as an emblem of free trade, and drew the following moral: "The artisan of Birmingham and Manchester - the seaman of London and Liverpool...has contributed by his labour to make the raisins of Malaga and the currants of Zante - the oranges of Algarve, the cinnamon of Ceylon, and the nutmegs of the Moluccas - of commercial value; and he has thus called them into existence as effectually as the labour of the native cultivator."9 Importantly, commodities were not always freighted negatively in Dickens's work. He was fascinated by what anthropologist Arjun Appadurai termed the social life of things and their ultimate meaning greatly depended on context and usage. 
We can get a better idea of Dickens's approach to the problem of the commodity if we consider the role of toys in Our Mutual Friend. The character of Jenny Wren, a "doll's dressmaker and manufacturer of ornamental pincushions and pen-wipers," is one of the moral cornerstones in the novel. Deformed and old before her time, the indefatigable Jenny works hard to support a drunken father and, like the aged Betty Higden (the other major centre of value in the novel) who prefers to tramp the countryside, selling trifles rather than enter the workhouse, she is fiercely independent. Jenny is linked to the good-hearted Riah in the text, who praises her handiwork - "a dazzling semicircle of dolls in all the colours of the rainbow" - that he notices when they pass a toyshop window. Jenny explains to him how she makes their outfits, complaining that the hardest part of the work is not the cutting out and sewing but the "trying-on," which means she has to "scud about town at all hours." Riah is ignorant of what “trying-on” entails, so Jenny elucidates: “"There's a Drawing Room, or a grand day in the Park, or a Show, or a Fete, or what you like. Very well. I squeeze among the crowd, and I look about me. When I see a great lady very suitable for my business, I say 'You'll do, my dear!' and I take particular notice of her, and run home and cut her out and baste her...I am making a perfect slave of her, with making her try on my doll's dress"” (431; bk. 3, ch. 2). In this way, Dickens laid bare the arduous female labour that had made possible the rapid expansion of the toy industry in mid-Victorian Britain (Brown K. D.). In a wonderful inversion that she obviously delights in, Jenny uses the bodies of the idle rich as models for her art. She remarks that the women probably imagine her to be staring admiringly at them, whereas as Jenny exclaims, "they're only working for my dolls!" One recollection in particular Jenny finds especially amusing, when the same model was made to try on twice in an evening, getting in and out of her carriage: “"That's Lady Belinda hanging up by the waist, much too near the gaslight for a wax one, with her toes turned in.'” Jenny thus takes revenge 
on a society whose structural inequalities she stoically endures by reifying the rich and transforming them into commodities from which she makes her living.

Not only do readers see something of the human labour that has produced these commodities in the novel, they are also encouraged to ponder the social life of toys. As part of their desire to share their good fortune, the Boffins seek out an orphan and alight on Betty Higden's dead daughter's child. We first meet poor Johnny, “angling for mud with a headless wooden horse and line," at the door of his grandmother's squalid dwelling. Initially reluctant to leave the old lady's care, Mrs Boffin eventually tempts him with promises of "toywonders" (196, 203; bk. 1, ch. 16; see also Hennelly). When Johnny falls ill, Mrs Boffin, Bella and Rokesmith call at a toy shop and to cheer him up buy him "that noble charger, a description of whose points and trappings had on the last occasion conciliated the then worldly-minded orphan, and also a Noah's ark, and also a yellow bird with an artificial voice in him, and also a military doll so well dressed that if he had only been of life-size his brother-officers in the Guards might never have found him out." As he lies dying in the children's hospital, Johnny bequeaths the toys to a restless boy in the next bed, who had looked over "to fortify himself with a view of the ark, and fell asleep" (322, 326-7; bk. 2, ch. 9). Undeniably a scene of cloying sentimentality, it is also much more than that. Toys are not only signs of a reified consumer culture but also offer real delights, engage the imagination and provide a refuge from the world of care and suffering, can soften even death. Children bring inanimate things to life, in this passage and elsewhere in Dickens's work, as a way of making their own lives more bearable. Truly loved objects comfort rather than mock their owners. 
Dickens may have drawn on an article by Henry Morley in Household Words here, which had described a poor working-class home in Bethnal Green in London's east end. The inhabitants had sold or pawned all their possessions after the main breadwinner had died, except for a child's toy - a monkey riding on a cock: "As the wheels rolled, it made music, and up scrambled the fourth child, a great baby boy. 'His grandmother gave him that,' the mother said. 'They had sold their bed, their clothes, but they had kept the plaything!',10 Adults are not entirely shut out from the children's world of things: when Betty Higden embarks to trade on the road, Boffin asks her what she has concealed on her person; "It was the man in the Guards who had been on duty over Johnny's bed. The solitary old woman showed what it was, and put it up quietly in her dress" (383; bk. 2, ch. 14). Thus, things often carried affective meaning and memory for Dickens, who clearly did not regard capitalist commodities simply as “documents of barbarism" (Benjamin 258; see also Piggott). His representation of the Veneerings' camels may bring to mind Marx's critique of the fetishism of commodities but Dickens did not subscribe to the labour theory of value despite his interest in the origin of goods and although this perhaps allowed him to attend closer to the social life of things, it also made it difficult for him to resolve satisfactorily the many contradictions exposed in his work. ${ }^{11}$

Toys in particular provide an important form of solace in the novel and point to the ways in which commodities are often imaginatively appropriated by their owners. However, they feature in the interstices of capitalist society and can be easily overlooked, hidden in the child's world or the pauper's dress; "Mammonism" may indeed be partially humanized by such means, Dickens maintains, though he also acknowledges that individual appropriation offers no general solution. For this, Dickens falls back on the bedrock of a feminized bourgeois home. The theme is ironically introduced through the figure of the listless, 
unsuccessful barrister, Eugene Wrayburn, a cigar-smoking flâneur and bored observer of middle-class culture. Wrayburn mocks the fashionable notion that goods exert a moral influence when describing his apartment: “'See!' said Eugene, 'miniature flour-barrel, rolling-pin, spice-box, shelf of brown jars, chopping-board, coffee-mill, dresser elegantly furnished with crockery, saucepans and pans, roasting jack, a charming kettle, an armoury of dish-covers. The moral influence of these objects, in forming the domestic virtues, may have an immense influence upon me"' (282; bk. 2, ch. 6). Deborah Cohen's work has illuminated how many middle-class men played an active role in home-making in the second half of the nineteenth century and has also underlined how the possession of things, furniture in particular, was thought to exert a moral influence after the "age of atonement" had waned (89-104; see also Tosh). Dickens's novel connects to such themes - his own keen interest in domestic furnishing has already been noted - but his presentation in the end is ironical, though not entirely despairing nor without hope. Towards the novel's close, for instance, Eugene is both redeemed and reborn when he defies social convention and marries Lizzie Hexam, therefore taking up Jenny Wren's challenge to 'reform and be a good dog' (234; bk. 2, ch. 2). The other happy young couple at the end of the novel, Bella and John Harmon, set up home in a neat, modest cottage. While Harmon works as a clerk in the City, Bella learns to cook and keep a tidy house with help from a badly written guide, "The Complete British Family Housewife," a thinly veiled dig at Mrs Isabella Beeton, whose bestselling cookbook was an icon of Victorian consumerism (665-6; bk. 4, ch. 5). Dickens weakly contests the rule of money when he remarks that Harmon, "cared, beyond all expression, for his wife, as a most precious and sweet commodity (my italics) that was always looking up, and that never was worth less than all the gold in the world" (667; bk. 4, ch. 5, see also Miller 157-8, and Orwell 125). 
However, this is all rather lame and unconvincing: the domestic virtues are no match for the Veneerings and their predatory gang. Whereas Dombey had to atone for his sins, in Our Mutual Friend Dickens implies that capitalists can now get away scot-free for their immoral practices. The development of corporate capitalism from mid-century meant that they now had less fear of retribution. Indeed, the stigma attaching to bankruptcy gradually lessened from the 1840s. The Companies Act of 1844 accorded legal status to joint-stock companies and after the Limited Liability Act of 1855, the Joint-Stock Companies Act of 1856 and the comprehensive Companies Act of 1862, shareholders of limited companies were only liable for the unpaid portion of their shares (Weiss 138; Poovey 156-65). Dickens's increasingly bleak social vision was based therefore on a realistic appreciation of the structural forces that under girded the power and status of individual capitalists. Though they have lived well beyond their means by virtue of credit, when the Lammles go bust the Veneerings' guests express general disbelief because, as the 'Father of the three hundred and seventy-five thousand pounds' protests, “"there is always such a thing as an adjustment of affairs, in the case of people of any standing at all'" (612; bk. 3, ch. 17). The fate of the Veneerings, who themselves eventually suffer a crash, is far more comprehensible: $\mathrm{Mr}$ Veneering simply resigns his parliamentary seat and lives on his wife's diamonds in Calais (792; bk. 4, ch. 17). In a hostile review in the Nation, the young Henry James complained that the novel was "poor with the poverty...of permanent exhaustion," though the issue was not merely a question of form as James implied but also involved the exhaustion of hope; at the end of the novel there is no doubt that the "Voice of Society" will continue to prosper (Ackroyd 967). 
The triumph of Society can be read every day on the streets of the metropolis. Their acquisitiveness produces the literal and metaphorical fog that poisons inhabitants and conceals social relationships.

It was a foggy day in London, and the fog was heavy and dark. Animate London, with smarting eyes and irritated lungs, was blinking, wheezing, and choking; inanimate London was a sooty spectre, divided in purpose between being visible and invisible, and so being wholly neither. Gaslights flared in the shops with a haggard and unblest air, as knowing themselves to be night-creatures that had no business abroad under the sun; while the sun itself when it was for a few moments dimly indicated through circling eddies of fog, showed as if it had gone out and were collapsing flat and cold. Even in the surrounding country it was a foggy day, but there the fog was grey, whereas in London it was, at about the boundary line, dark yellow, and a little within it brown, and then browner, and then browner, until at the heart of the City - which call Saint Mary Axe - it was rusty-black. From any point of the high ridge of land northward, it might have been discerned that the loftiest buildings made an occasional struggle to get their heads above the foggy sea, and especially that the great dome of Saint Paul's seemed to die hard; but this was not perceivable in the streets at their feet, where the whole metropolis was a heap of vapour charged with muffled sound of wheels, and enfolding a gigantic catarrh (417; bk. 3, ch. 1).

In this remarkable passage, Dickens vividly conveys the idea that the structural immorality of free market capitalism has dissolved both sensory and ethical boundaries. It has become almost impossible to differentiate any longer between the real and the unreal in this modern Babylon, where even the source of life itself "showed as if it had gone out and were 
collapsing flat and cold." Moreover, at the very centre of this city of extremes, surrounded by concentric circles of obscurity, lies the hellish "rusty-black" financial centre of global capitalism. Christian morality no longer offers a guide - "the great dome of Saint Paul's seemed to die hard" - for those who grope their way through life within "a gigantic catarrh." Toy-wonders and the domestic virtues provide small consolations in such a city.

\section{Conclusion}

Given Dickens's pathologisation of Victorian consumer culture in Our Mutual Friend, it was hardly surprising that the novel was a flop, relatively speaking. Sales fell off rapidly, dropping 5,000 between the first and second numbers, and by the final double number sales were down to 19,000 from 35,000 . Dickens was financially secure by this time so was not overly concerned; he was making money from All The Year Round and was working his copyrights, which meant that his income steadily increased during this period (Ackroyd 952). Critics have often portrayed Dickens as either an essentially "middle-class" writer or else have sought to align him with the literature of popular radicalism but it is interesting to note that he fell out of favour with very different constituencies before the end of his career (Haywood 163; Ledger 150). Many of the polite journals attacked Dickens for supposedly caricaturing the rich as we have seen, while the radical press condemned him as a hypocrite, reckoning that he "struck twelve o'clock all at once" with his early success (Reynolds's 3). After his death in 1870, the Graphic could remark with justification that Dickens's popularity was largely "confined to the middle and upper classes" and that he had "yet to become...the favourite of the poorer classer" (Patten 327). Only after the writer's body was buried against his own wishes in Poet's Corner, Westminster Abbey - "a species of theft" according to Orwell - was Dickens transformed into a "national institution" whose writings were regarded as helping to heal the rift between classes and cultures (Orwell 80-1). 
However, Dickens's mature work demonstrated the impossibility of resolving effectively the contradictions of consumer culture by moralising free trade capitalism and bridging the gulf between economics and ethics. For sure, finance capitalists and speculators come off worse in Our Mutual Friend; as Patrick Brantlinger observed Dickens had a soft spot for industrialists - Josiah Bounderby was an exception to the rule. Nevertheless, as we have seen, in this work the corrosive power of mammon and the inordinate desire for goods is shown to deform social relations throughout the whole of society, from the Veneerings down to the Boffins and everybody else. Dickens fully appreciated that the consumer culture that modern capitalism had produced brought benefits for some, though he also had no doubt that it had made it more difficult for individuals to treat each other as people rather than as things. His trenchant, radical critique, more telling for being voiced by one who had embraced the free trade utopia and understood the allure of material goods only too well, was pushed to one side after his death in favour of an image of Dickens as a spokesman for liberal humanitarianism; Harriet Martineau was not being complimentary when she described Dickens as a "humanity monger" (Brantlinger 113, 117). This is precisely what he became in the decades after his death, not a probing critic of consumer culture but instead a writer who did "more to draw English people together than any other influence at the time" (Hammond $113,117)$. It has proved very difficult to unpick this powerful mythology, not least because it was encouraged by Dickens in his own lifetime but also because it contained more than a grain of truth. ${ }^{12}$

\section{Notes}

1 On Dickens's reaction to the Great Exhibition see his letter to Mrs Watson in Storey, Tillotson and Burgis 428. 
2 Patten, 218-20; Darwin, 197-208; John, 50-55; Williams, "Advertising and Fiction."

3 The context is discussed in detail by Alborn, Cotsell, Wagner, and Taylor, Creating Capitalism 176-209. Taylor presents an over-sanguine account of legal constraints after mid-century in Boardroom Scandal.

4 "Mammonism." According to the Oxford English Dictionary, Carlyle was among the first to use the term in Past and Present (1843): "In whirlwinds of fire, you and your Mammonisms, Dilettantisms [etc.]...shall disappear!”

$5 \quad$ Note Patten and Miller 146-7. The latter suggests that Dickens should be seen as a capitalist rather than a labourer.

6 See Van Ghent, Richards, and Williams, "Pot-Bellied Salt-Cellars and Talking Plates."

7 See Burnett, Smith, and Waters, 47-50, who shows how Dickens's Household Words helped publicize the findings of Hassall's analytical sanitary commission.

8 For the debate on taste see, inter alia, Pevsner and Kriegel.

9 “A Christmas Pudding.” See also Miller 122-3, Young, and Waters 107-9.

10 “The Quiet Poor." In a letter to Morley about the article Dickens wrote; "I think it is absolutely impossible that it should have been better done." See Lohrli 572.

11 In her fascinating book, Freedgood distinguishes between what she calls "thing culture" and "commodity culture," arguing that the former preceded and overlapped with the latter in Victorian Britain. This she believes gave writers like Dickens the space to develop a more nuanced reading of the metonymic meanings embedded in things. Freedgood's attempt to differentiate between between "thing culture" and "commodity culture" is ultimately unconvincing, however, as commodity production and consumption had already been generalized by the mid nineteenth century. It is 
misleading therefore to claim that "the things of the Dickens novel are not, in general, commodified" $(7,106)$. Note also Sattaur.

12 See the comments of early Labour MPs in, "The Labour Party and the Books that Helped to Make it," who admitted to being more influenced by Dickens's novels than the works of Marx.

\section{Works cited}

“A Christmas Pudding.” Household Words 21 Dec. 1850: 301.

“A House Full of Horrors.” Household Words 4 Dec. 1852: 265-70.

Ackroyd, Peter. Dickens. London: Sinclair-Stevenson, 1990.

Appadurai, Arjun, ed. The social life of things. commodities in cultural perspective.

Cambridge: Cambridge UP, 1986.

Alborn, Timothy. Conceiving companies: joint-stock politics in Victorian England. London:

Routledge, 1998.

Benjamin, Walter. Illuminations. London: Fontana, 1973.

Brantlinger, Patrick. The Spirit of Reform. British Literature and Politics, 1832-1867.

Cambridge: Cambridge UP, 1977.

Briggs, Asa. Victorian Things. London: Penguin Books, 1990.

Brown, James M. Dickens: Novelist in the Market-Place. London: Macmillan, 1982.

Brown, K. D. The British Toy Business. A History since 1700. London: The Hambledon Press, 1996.

Burnett, John. Plenty and Want: A Social History of Diet in England from 1815 to the Present Day. London: Nelson, 1966.

Buzard, James. The Beaten Track: European Tourism, Literature, and the Ways to “Culture,” 1800-1918. Oxford: Oxford UP, 1993. 
Church, Roy. "Advertising consumer goods in nineteenth century Britain: reinterpretations.” Economic History Review 53.4 (2000): 621-45.

Cohen, Deborah. Household Gods. The British and Their Possessions. New Haven: Yale UP, 2006.

Cotsell, Michael.'The Book of Insolvent Fates: Financial Speculation in Our Mutual Friend." Dickens Studies Annual 13 (1984): 125-42.

Darwin, Bernard. The Dickens Advertiser: A Collection of the Advertisements in the Original Parts of Novels. London: Elkin Matthews \& Marrot, 1930.

Dickens, Charles. Our Mutual Friend (1865). London: Penguin Books, 1997.

Fielding, K. J. "Charles Dickens and the Department of Practical Art.” Modern Language Review, 48.3 (1953): 270-77.

Finn, Margot. The character of credit: personal debt in English culture, 1740-1914.

Cambridge: Cambridge UP, 2003.

Fraser, W. H. The Coming of the Mass Market 1850-1914. London: Macmillan, 1981.

Freedgood, Elaine. The Ideas in Things: Fugitive Meaning in the Victorian Novel. (Chicago: Chicago UP, 2006.

Hammond, J. L. and Barbara. The Age of the Chartists, 1832-1854. London: Longmans, Green, 1930.

Haywood, Ian. The revolution in popular literature: print, politics, and the people, 1790 1860. Cambridge: Cambridge UP, 2004.

Hennelly, Mark. “Toy Wonders.” Dickens Quarterly 12.2 (1995): 60-72; 12.3 (1995): 95107.

Hoppen, Theodore. The Mid-Victorian Generation, 1846-1884. Oxford: Oxford UP, 1998. John, Juliet. Dickens and Mass Culture. Oxford: Oxford UP, 2010. 
Jones, Owen. On the True and the False in the Decorative Arts: Lectures delivered at Marlborough House, June 1852. London: Strangeways and Walden, 1863.

Kriegel, Lara. Grand designs: labor, empire, and the museum in Victorian culture. Durham: Duke University Press, 2007.

Ledger, Sally. Dickens and the popular radical imagination. Cambridge: Cambridge UP, 2007.

Lohrli, Anne. "Household Words”. A Weekly Journal 1850-1859. Conducted by Charles

Dickens. Toronto: University of Toronto Press, 1973.

Maidment, Brian. Dusty Bob. A cultural history of dustmen, 1780-1870. Manchester:

Manchester University Press, 2007.

"Mammonism." Oxford English Dictionary Online. http://0-

www.oed.com.serlib0.essex.ac.uk/view/Entry/113175?redirectedFrom=mammonism\#eid. Accessed 6 Dec. 2014.

Miller, Andrew H. Novels behind glass. Commodity culture and Victorian narrative.

Cambridge: Cambridge UP, 1995.

Orwell, George. Decline of the English Murder and Other Essays. London: Penguin Books, 1965.

Patten, Robert L. Charles Dickens and His Publishers. Oxford: Oxford University Press, 1978.

Pevsner, Nikolaus. High Victorian Design. A Study of the Exhibits of 1851. London: Architectural Press, 1951.

Piggott, Gillian. Dickens and Benjamin: moments of revelation, fragments of modernity. Farnham, Ashgate, 2012.

Poovey, Mary. Making a Social Body. British Cultural Formation, 1830-1864. Chicago: Chicago UP, 1995. 
Poovey, Mary. "Writing about finance in Victorian England: disclosure and secrecy in the culture of investment." Victorian Studies 45.1 (2002): 17-41.

Reynolds's Newspaper. 14 June 1857.

Richards, Thomas. The Commodity Culture of Victorian England: Advertising and Spectacle, 1851-1914. London: Verso, 1990.

Said, Edward W. Orientalism. London: Routledge \& Kegan Paul, 1978.

Sattaur, Jennifer. "Thinking objectively: an overview of "thing culture” in Victorian studies." Victorian Literature and Culture 40.1 (2012): 347-57.

Saturday Review. 11 Nov. 1865.

Slater, Michael. "Carlyle and Jerrold into Dickens: A Study of The Chimes." Nineteenth Century Fiction 24.4 (1970): 506-26.

Smith, S. D. “Coffee, microscopy, and The Lancet's analytical sanitary commission." Social History of Medicine 14.2 (2001): 171-97.

Stedman Jones, Gareth. "The redemptive power of violence? Carlyle, Marx and Dickens." History Workshop Journal 65 (2008): 1-22.

Storey, Graham, Tillotson, Kathleen and Burgis, Nina (eds), The Letters of Charles Dickens. Volume IV, 1850-1852. Oxford: Oxford University Press, 1988.

Taylor, James. Creating Capitalism. Joint-Stock Enterprise in British Politics and Culture, 1800-1870. Woodbridge: Royal Historical Society/Boydell Press, 2006.

Taylor, James. Boardroom scandal. The criminalization of company fraud in nineteenthcentury Britain. Oxford: Oxford UP, 2013.

“The Age of Veneer.” Fraser's Magazine, Sept. 1850: 244; Jan. 1852: 90.

“The British Dervish.” Household Words, 15 Mar. 1856: 196-203.

“The Grammar of Ornament." Fortnightly Review, 15 May 1865: 24-5. 
"The Labour Party and the Books that Helped to Make it." Review of Reviews, June 1906: $568-82$.

“The Magic Troughs at Birmingham.” Household Words, 25 Oct. 1851: 113-7.

“The Quiet Poor.” Household Words, 15 Ap. 1854: 202.

Tosh, John. A man's place: masculinity and the middle-class home in Victorian England.

New Haven: Yale UP, 1999.

Van Ghent, Dorothy. The English Novel: Form and Function. New York: Harper Torchbook, 1961.

Wagner, Tamara S. Financial Speculation in Victorian Fiction. Plotting Money and the Novel Genre, 1815-1901. Columbus: Ohio State UP, 2010.

Walder, Dennis. Dickens and Religion. London: Allen \& Unwin, 1981.

Waters, Catherine. Commodity Culture in Dickens's 'Household Words' (Aldershot, 2008).

Weiss, Barbara. The Hell of the English. Bankruptcy and the Victorian Novel. Lewisburg: Associated University Presses, 1986.

Williams, Andy. "Pot-Bellied Salt-Cellars and Talking Plates: Fetishism and Signification in Our Mutual Friend." Consuming Culture in the Long Nineteenth Century. Narratives of Consumption, 1700-1900. Ed. Tamara S. Wagner and Narin Hassan. Lanham: Lexington Books, 2007.

Williams, Andy. "Advertising and Fiction in The Pickwick Papers." Victorian Literature and Culture 38.2 (2010): 319-35.

Young, Paul. "Economy, Empire, Extermination: The Christmas Pudding, the Crystal Palace and the Narrative of Capitalist Progress." Literature \& History 14.1 (2005): 14-30. 